Lynn M. Barry

Lynn M. Barry is an economist at the Federal Reserve Bank of St.

Louis. Dawn M. Peterson provided research assistance.

\title{
District Bank Performance in 1987: Bigger Is Not Necessarily Better
}

II the Eighth Federal Reserve District, 1987 was a year of mixed performance. ${ }^{3}$ Latin-Americanrelated loan loss provisions at the larger banks were the primary reason that commercial bank profits of $\$ 934.7$ million in the District last year fell below 1986 profits of $\$ 976.7$ million. This decline, however, was small relative to the national decline. Commercial banks in the United States earned $\$ 3.3$ billion in 1987 , a substantial decrease from $\$ 17.3$ billion in $1986 .{ }^{2}$

Some gains were made in 1987 by smaller District banks, which posted higher earnings as loan loss provisions and loan charge offs declined. Asset quality improved considerably at small, agricultural banks as nonperforming assets decreased, loan losses fell substantially, reserves for any future problems were maintained and capital was increased.

Bank failures, which increased nationally from 138 in 1986 to 184 in 1987, declined from five to two in the Eighth District. These two banks, nei- ther of which was a member of the Federal Reserve System, had combined assets of $\$ 47.1$ million, only .04 percent of total District bank assets.

This article compares the performance and financial circumstances of Eighth District commercial banks with their national counterparts across several asset-size categories. An assessment of bank earnings, asset quality and capital adequacy then provides some useful information on the financial condition, regulation compliance and operating soundness of the regional banking industry.

\section{EARNINGS}

\section{Returns on Assers and Equity}

There are two standard measures of bank performance: the return on average assets $(\mathrm{ROA})$ and the return on equity (ROE) ratios. The ROA ratio, calculated by dividing a bank's net income after taxes by its average fourth-quarter assets, shows how well a bank's management is employing its

The Eighth Federal Reserve District consists of the following: Arkansas, entire state; Illinois, southern 44 counties; Indiana, southern 24 counties; Kentucky, western 64 counties; Mississippi, northern 39 counties; Missourt, eastern and southern 71 counties and the City of St. Louis; Tennessee, western 21 counties.

2The national figures for 1987 are adversely affected by large oil- and real estate-related loan losses incurred by banks in the Southwest. 
Table 1

Return on Average Assets and Return on Equity

\begin{tabular}{|c|c|c|c|c|c|c|}
\hline & \multicolumn{2}{|c|}{1997} & \multicolumn{2}{|c|}{1986} & \multicolumn{2}{|c|}{1985} \\
\hline & District & U.S. & District & U.s. & Distales & Gs. \\
\hline \multicolumn{7}{|c|}{ Beturn on Average Assets (ROA) } \\
\hline Albanks & $0.81 \%$ & $0.11 \%$ & $0.68 \%$ & $0.62 \%$ & $0.84 \%$ & $0668 \%$ \\
\hline - 825 millon in assets & 0.10 & 0.17 & 070 & 004 & 1070 & 028 \\
\hline 925550 million & 0.90 & 049 & 084 & 0.44 & 088 & 0.67 \\
\hline 550.5100 millon & 095 & 068 & 093 & 062 & 0.96 & 074 \\
\hline 31008300 nition & 0.95 & 0.78 & 0.88 & 0.70 & 0.97 & 088 \\
\hline 8300 wlllon o r billon & 107 & 062 & 0.67 & 059 & 0.54 & 076 \\
\hline (4) 1870 billog & 0.51 & 10.52 & 0.98 & 0.74 & 0.07 & 085 \\
\hline \multicolumn{7}{|l|}{ Return on Equity (nof) } \\
\hline Allbanks & $10,3 \%$ & $1.65 \%$ & $1,28 \%$ & $959 \%$ & $10,86 \%$ & $10,64 \%$ \\
\hline .625 nilion hrassets & 739 & 1,72 & $7+6$ & 0.46 & 7,60 & 2800 \\
\hline$\$ 25550$ nilion & 10.14 & 562 & 974 & 6,6 & 9.27 & 778 \\
\hline 65088100 nivilon & 10.93 & 8.8 .16 & 10.96 & 762 & 11,46 & 8912 \\
\hline 7100.5300 minion & 11 & 10.08 & 1,10 & 929 & 1243 & $1,1,16$ \\
\hline 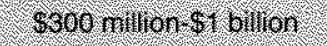 & 1367 & 8.05 & 9.82 & $8-41$ & 704 & 1036 \\
\hline $6 / \sin 10$ billor) & 8.96 & .8 .29 & 1459 & 11.68 & 13.4 & 1349 \\
\hline $2.510 \mathrm{billon}$ & $11 \mathrm{~A}$ & 15.10 & $1 / \mathrm{A}$ & 10.72 & N. $\mathrm{A}$. & 10.00 \\
\hline
\end{tabular}

avallable resources. The ROE ratio is obtained by dividing a bank's net income after taxes by its equity capital. ROE measures how well management is utilizing the stockholders' investment measured on a book-value basis. ${ }^{*}$

As table 1 reports, the 1987 average ROA and ROE for Eighth District banks were 0.81 percent and 10.31 percent, respectively. These figures exceeded the national average ROA of 0.11 percent and ROE of 1.85 percent. Eighty-two banks in the District, 6 percent of all Eighth District banks, reported negative earnings in 1987; nationally, almost 17 percent of commercial banks reported losses for the vear. The U.S. ROA and ROE figures were heavily influenced by poor earnings at the nation's largest banks (those with more than $\$ 10$ billion in assets). Excluding these banks from the national ratios yielded an ROA of 0.58 percent and an ROE of 8.14 percent for 1987 . After this adjustment, however, District bank averages continued to exceed those of the nation.

Table 1 also shows ROAs and ROEs for seven asset-size classes of commercial banks. Across most asset-size categories, except $\$ 1-\$ 10$ billion, Fighth District banks reported higher returns than their national peers in 1987. District ROAs and ROEs were maintained or increased from 1986 across all size groups except the largest $(\$ 1-\$ 10$ billionl. Large District banks' ROAs averaged 0.51 . percent in 1987 , down from 0.98 percent in 1986 . This category of banks faced a deterioration in the quality of their foreign loan portfolio during the year, resulting in higher loan loss provisions which directly offset eamings. The remaining cate
${ }^{3}$ Equity capital includes common and perpetual preferred stock, surplus, undivided profits and capital reserves.

${ }^{4} \mathrm{~A}$ major concern with ROA, ROE and other performance measures is that they are calculated using the book values of assets, liabilities and equity. Book values fail to recognize changes in the value of assets, llabilities and equity between their initial placement on the books of the institution and their removal by sale, repayment, maturity or charge off. In other words, book value is the historic, not market, value of an asset or liability. 


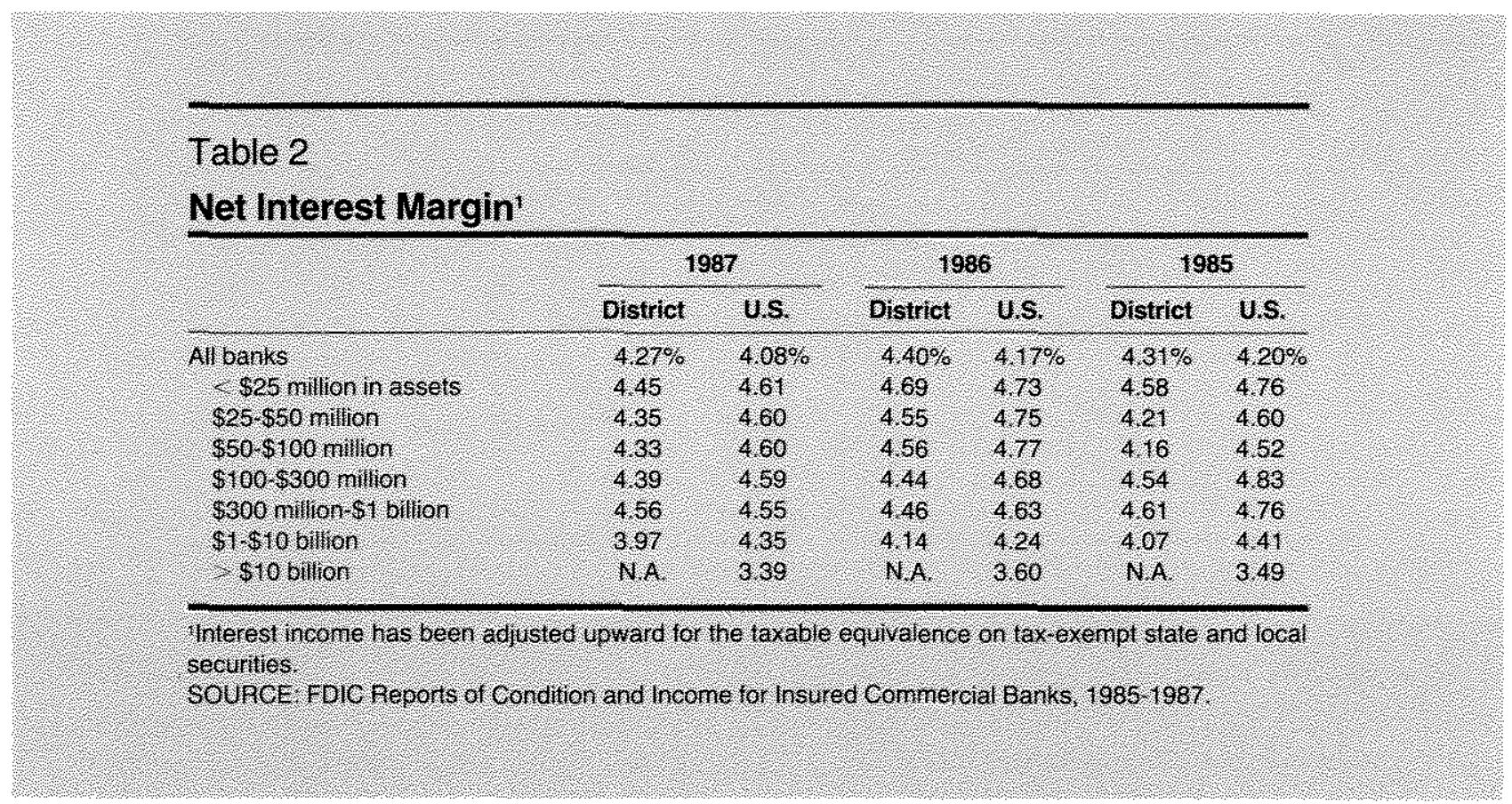

gories of District banks, on the other hand, reduced their loan loss provisions, which helped to boost both their ROA and ROE ratios.

\section{MAWGINANAESSS}

The financial success of a bank depends on its management's ability to generate sufficient revenue while controlling costs. Bank managers make numerous decisions during the year concerning asset and liability management the pricing of services and operating expenses. Two important measures of the results of these decisions are net interest and net noninterest margins.

\section{Ne⿱ Interest Margin}

Net interest margin is the difference between interest income and interest expense as a percentage of average fourth-quarter earning assets. "This ratio indicates how well interest-earning assets are being employed relative to interest-bearing liabilities. ${ }^{6}$

On the asset side, this includes both interest income and fees related to interest-earning assets.
Some examples are interest on loans, points on loans, income on tax-exempt municipal loans and bonds and income from holdings of U.S. government securities. On the liability side, interest expense includes the amount paid on all categories of interest-bearing deposits, federal funds purchased and capital notes. In simplest terms, net interest margin is the difference between what a bank earned on loans and investments and what it paid its depositors relative to average eaming assets.

Table 2 shows the average net interest margin for commercial banks on a national and District level. As the table shows, the average spread between interest income and interest expense as a percent of average fourth-quarter earning assets was 4.27 percent for District banks in 1987 , compared with 4.08 percent for the nation. Average net interest margins at District banks were lower in 1987 than in 1986. This held true not only in the aggregate, but across most asset-size categories as well.

Because of the poor performance of the large banks, focusing on the overall average results con-
${ }^{5}$ Earning assets include: loans (net of unearned income) in domestic and foreign oftices; lease-financing receivables; obligations of the U.S. government, states and political subdivisions and other securities; assets held in trading accounts; interest-bearing balances due from depository institutions; federal funds sold and securities purchased under agreements to resell.
${ }^{6} \mathrm{~A}$ bank should be concerned not only with the level of the net interest margin, but also with the variability of the net interest margin over time. With volatile interest rates, the stability of the net interest margin indicates that the interest sensitivity of assets and liabilities is matched. 
Table 3

Net Noninterest Margin

\begin{tabular}{|c|c|c|c|c|c|c|}
\hline & \multicolumn{2}{|c|}{1987} & \multicolumn{2}{|c|}{1986} & \multicolumn{2}{|c|}{1985} \\
\hline & District & 0.5 & District & u.s. & District & U.S. \\
\hline Albanks & $198 \%$ & $187 \%$ & $197 \%$ & $193 \%$ & $200 \%$ & $1,95 \%$ \\
\hline $18 \$ 25$ million nassets & $250 \%$ & 289 & 251 & 2.91 & 249 & 290 \\
\hline s25 550 rullion & 216 & 258 & 213 & 2.58 & 211 & 252 \\
\hline$\$ 50$ \$ 100 millon & 203 & 2,44 & 207 & 2.47 & 2.04 & 2,4 \\
\hline$\$ 100 \$ 300$ millon & 203 & 234 & 201 & 236 & 202 & 238 \\
\hline$\$ 300$ millon $\$ 1$ bllion & 198 & 228 & 221 & 235 & 249 & 235 \\
\hline s1s s10 bilion & 175 & 197 & 162 & 196 & 164 & 201 \\
\hline \$ S10bilion & N.A. & 134 & $\mathrm{NA}$ & 1,43 & $\mathrm{NA}$ & 141 \\
\hline
\end{tabular}

NOTE Smaller net noninterest nargins indicate better bank performance, holding all ofher things constant.

SOURCE, FDIC REport s of Condition and Income for Insured Commercal Banks, 19851987

ceals differences across asset-size classes. $A$ closer inspection of the categories reveals that banks across the nation generally outperformed banks in the Eighth District. For five of the six categories encompassing banks with assets less than $\$ 10$ billion. District averages in 1987 were below the national average. The overall national average was adversely affected by those banks with assets greater than $\$ 10$ billion none of which are in the Eighth District). This category of banks experienced a significant decline in net interest margin, in part, because of lost income from nonperforming foreign loans.

\section{Net Nontherest Margin}

The net noninterest margin is an indicator of the efficiency of a bank's operations and its pricing and marketing decisions. The net noninterest margin is the difference between other (noninterest) income and noninterest expense as a per cent of average fourth-quarter assets. Since noninterest expense generally exceeds other income, the calculation yields a negative number; it is common practice, however, to report the net noninterest margin as a positive number. Thus, smaller net noninterest margins indicate better bank performance, holding all other things constant.

As a supplement to income generated from interest -earning assets, banks have been concentrating their efforts on fee income. Noninterest income derived from bank services and sources other than interest-earning assets has increased as banks seek to price more of their products explicitly. Sources of noninterest income include fees for checking accounts, discount brokerage services, credit cards, fiduciary activities, mortgage loan servicing and safe deposit box rentals. Noninterest expense (overhead) includes all the expense items involved in overall bank operations, such as employee salaries and benefits, as well as expenses of premises and fixed assets. Noninterest expense also covers such items as director' fees, insurance premiums, legal fees, advertising costs and litigation charges.

Noninterest expenses have been moving upward for the past several years in both the District and the nation. As a result, banks are closely monitoring personnel and occupancy costs in an effort to boost profits. Some banks have elected to reduce staff to streamline operations. In adtition, mergers and consolidations have allowed banks the opportunity to centralize operations, improving efficiency as a result of better economies of scale.

Table 3 shows the net noninterest margin for banks in the nation and the Eighth District grouped by various asset sizes. District banks in 1987 outperformed their national counterparts across all asset sizes. In the aggregate, however, the nation outperformed the District primarily because of the pricing strategies and operating efficiencies of banks with assets greater than $\$ 10$ billion. These large banks contimue to expand their noninterest sources of income relative to their noninterest expenses. Smaller institutions, on the other hand, have generated much slower growth of noninterest income.

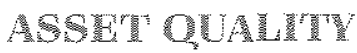

Asset quality is a primary factor influencing the banking industry's earnings pattern. With loan 
Table 4

Nonperforming Loans as a Percentage of Total Loans

\begin{tabular}{|c|c|c|c|c|c|c|}
\hline & \multicolumn{2}{|c|}{1987} & \multicolumn{2}{|c|}{1986} & \multicolumn{2}{|c|}{1985} \\
\hline & Distict & U/S. & Distict & U.S. & District & US. \\
\hline Alloanks: & $2.11 \%$ & $350 \%$ & $216 \%$ & $27 \%$ & $2.49 \%$ & $2.83 \%$ \\
\hline Y) $\$ 25$ mition no assets & 208 & 317 & 2,68 & 3.76. & 3.26 ? & 3.73 \\
\hline$\$ 25,550$ milion & 2,15 & 2,77 & 261 & 3.19 & 305 & 3,32 \\
\hline S50-8 100 nIIMon & 2.06 & 245 & 2.47 & 293 & 2.67 & 306 \\
\hline 81005300 milion & $\sqrt{105}$ & 220 & 204 & 254 & 2.11 & 258 \\
\hline 8000 nillon 81 billon & 1,47 & 2.31 & 2.33 & 251 & 265 & 246 \\
\hline S.S 10 billon & 244 & 2,4 & 181 & 206 & 2,0 & 224 \\
\hline 48,6161100 & $\mathrm{NA}$ & 526 & 10. & 3.37 & Na & 3.34 \\
\hline
\end{tabular}

SOURCE FDLC Repolts of Gondition ahd 1 home for lisured Commerclal Banks 1985.1987 .

losses rising over the past fow years at many commercial banks, investors and regulators alike are placing added focus on asset quality in assessing the health of the banking industry.

Asset quality typically is measured by two indicators. The first measure, the nonperforming loan rate, indicates not only the current level of problem loans but also the potential for future loan losses. The second indicator, the ratio of net charge offs to total loans, shows the percentage of loans (adjusted for recoveries) actually written of the bank's books.

\section{Nonperforning Loans}

Nonperforming loans are composed of two categories: 1) nonaccrual loans, i.e., those loans for which a bank is recording interest only when cash payments are received, and 2 ) loans past due 90 days or more. As table 4 reports, Eighth District banks' nomperforming loans as a share of total loans fell slighty from 2.16 pecent in 1986 to 2.11 percent in 1987, while rising nationally from 2.77 percent to 3.50 percent.

The dollar volume of nonperforming loans is heavily concentrated at the largest banks in the District and the nation. The nonperforming loan rate at District banks with assets between $\$ 1$ billion and $\$ 10$ billion rose from 1.81 percent in 1986 to 2.44 percent in 1987 . The average nonperforming loan rate for similar sized banks across the nation rose from 2.06 percent 102.42 percent during the same period. Nonperforming loans at the largest banks in the nation rose to 5.26 percent of total loans in 1987, up from 3.37 percent at yearend 1986. In 1987, many of these large banks placed millions of their Latin American loans on a nonaccrual status. The most notable of these were loans to Brazil, which were classiffed as nonaccrual in february of last year. This means that interest payments will be counted toward the bank's earnings only when actually received. $A$ bank usually places a loan on nonaccrual status when the borrower has failed to make payments. While several District banks with assets greater than $\$ 1$ billion reported increased levels of nonperforming loans resulting from Latin debt, smaler banks improved in this area during the past year. Banks with assets less than $\$ 25$ million saw nomperforming loans fall to 2.08 percent of total loans, down from 2.68 percent in 1986. This strong improvement in asset quality was likewise reported by banks with assets between $\$ 25-\$ 50$ million and \$50-\$100 million.

Another indicator of asset quality is the number of banks at which the dollar volume of nonperforming loans exceeds primary capital. At year-

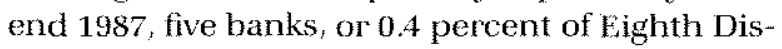
trict banks, had nomperforming assets that exceeded their primary capital, compared with 10 banks in 1986 . Nationally, 326 banks, or 2.4 percent of all banks, had nomperforming loans in excess of primary capital, down from 409 banks at yearwend 1986.

Chart 1 compares nonperforming loans by type of loan for Eighth District banks. At year-end 1987, nomperforming agricultural loans as a percent of total agricultural loans were 4.76 percent, down from 5.72 percent in 1986. Nonperforming commercial loans declined to 3.86 percent of commercial loans, down from 4.02 percent in 1986 . Consumer nomperforming loans, which accounted for 0.80 percent of all consumer loans outstanding in 1986, fell to 0.67 percent in 1987 . Lastly, real estate 
Chart 1

\section{Nonperforming Loans \\ as a Percentage of Total Loans by Category \\ Eighth District}

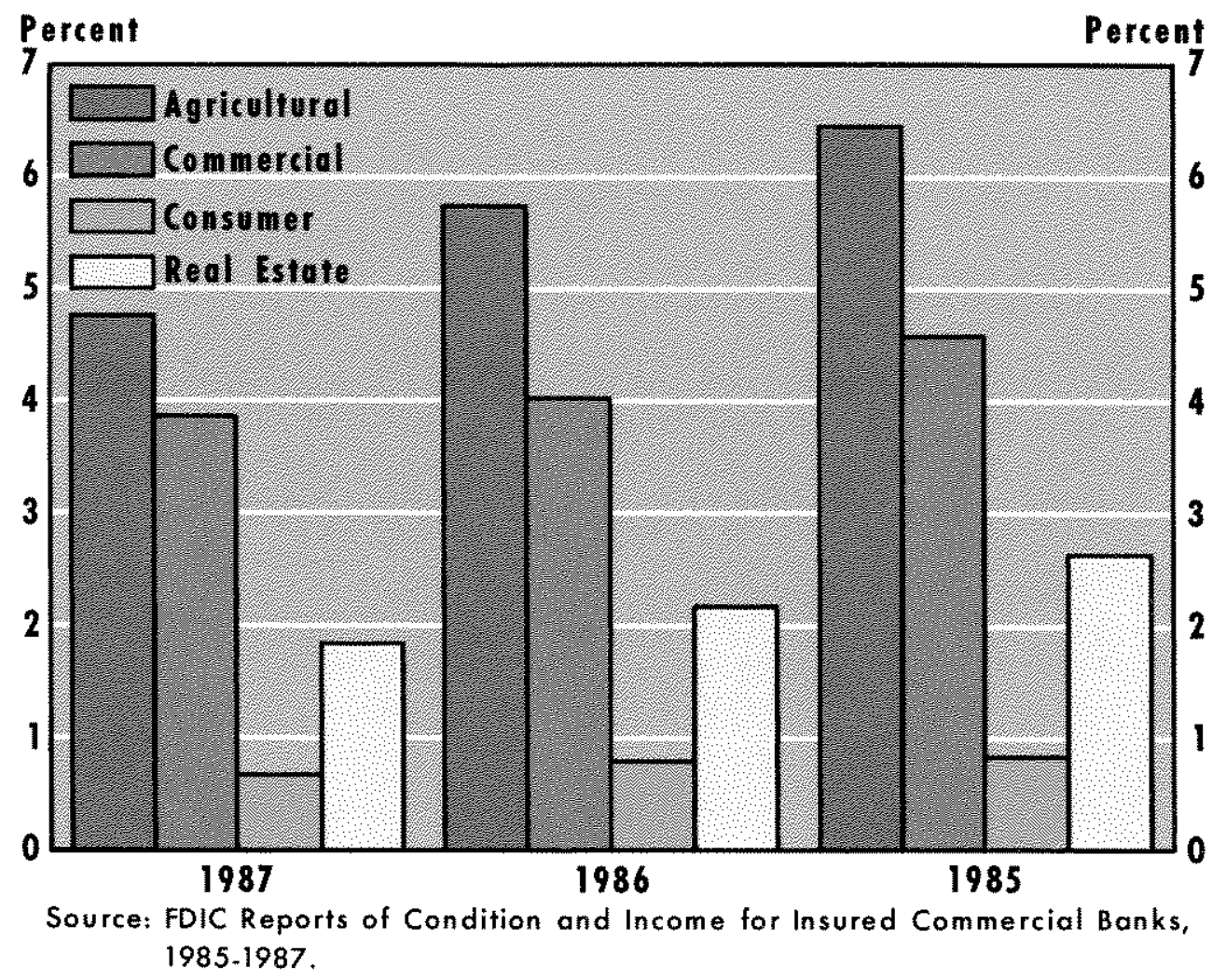

nonperforming loans also declined in 1987 , falling to 1.83 percent of total real estate loans, compared with 2.17 percent in 1986 .

\section{LOAn LCSECS}

The most direct measure of a bank's loan problems is the percentage of loans charged off during the year. As table 5 shows, the average charge-off rate at banks in the Eighth District, which had been rising in the early 1980 s, declined considerably in 1987. Net loan charge-offs ladjusted for recoveries) were 0.70 percent at year-end 1987 , compared with 0,88 percent in 1986 . Nationally, the average aggregate ratio of net loan losses to total loans fell from 0.93 percent in 1986 to 0.88 percent in 1987. Across all asset-size categories, 1987 net loan losses as a percentage of total loans at District banks were lower than at similar-sized banks in the nation.
Table 6 shows the distribution of loan losses by type of loan. For both the nation and the District, commercial loan losses constitute the greatest percentage of overall loan loss: more than 50 percent of all District charge-offs are commercial loans. The percent of District commercial loan charge-offs, however, is falling: 51.55 percent at year-end 1987, compared with 62.24 percent in 1986. Farm-related charge-offs declined considerably in 1987; they now account for 8.26 percent of total District loan losses, compared with 16.24 percent in 1986. Consumer charge-offs, meanwhile, rose in 1987 to 23.24 percent of total District loan losses, up from 18.65 percent in 1986 . Foreign office loans that were classified as a loss rose to 1.79 percent of total loans in the District. Nationally, this category of loan losses rose to 6.32 percent, up from 1.14 percent in 1986.

Cham 2 compares loss rates for specific loan 
Table 5

Net Loan Losses as a Percentage of Total Loans

\begin{tabular}{|c|c|c|c|c|c|c|}
\hline & \multicolumn{2}{|c|}{1987} & \multicolumn{2}{|c|}{1086} & \multicolumn{2}{|c|}{1985} \\
\hline & District & 1,5 & Distrigl & Us. & District & 1.s. \\
\hline 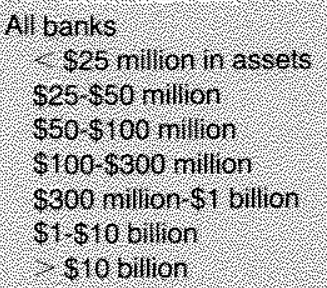 & $\begin{array}{l}070 \% \\
0.93 \\
072 \\
070 \\
0.67 \\
071 \\
0.68 \\
1,4\end{array}$ & $\begin{array}{l}0.68 \\
149 \\
16 \\
0.94 \\
076 \\
0.85 \\
0.85 \\
0.88\end{array}$ & $\begin{array}{l}0.88 \% \\
1.31 \\
1.05 \\
0.98 \\
0.92 \\
0.57 \\
17\end{array}$ & $\begin{array}{l}0.93 \% \\
2,00 \\
1,61 \\
1,86 \\
102 \\
0.96 \\
0.82\end{array}$ & $\begin{array}{l}0.69 \\
1,52 \\
1.80 \\
1.09 \\
0.72 \\
0.78 \\
0.60 \\
110\end{array}$ & $\begin{array}{l}0.619 \\
1.68 \\
1,22 \\
0.84 \\
0.74 \\
0.64 \\
0.7\end{array}$ \\
\hline
\end{tabular}

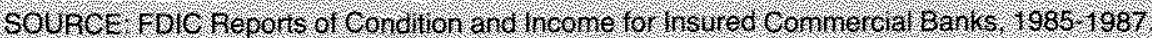

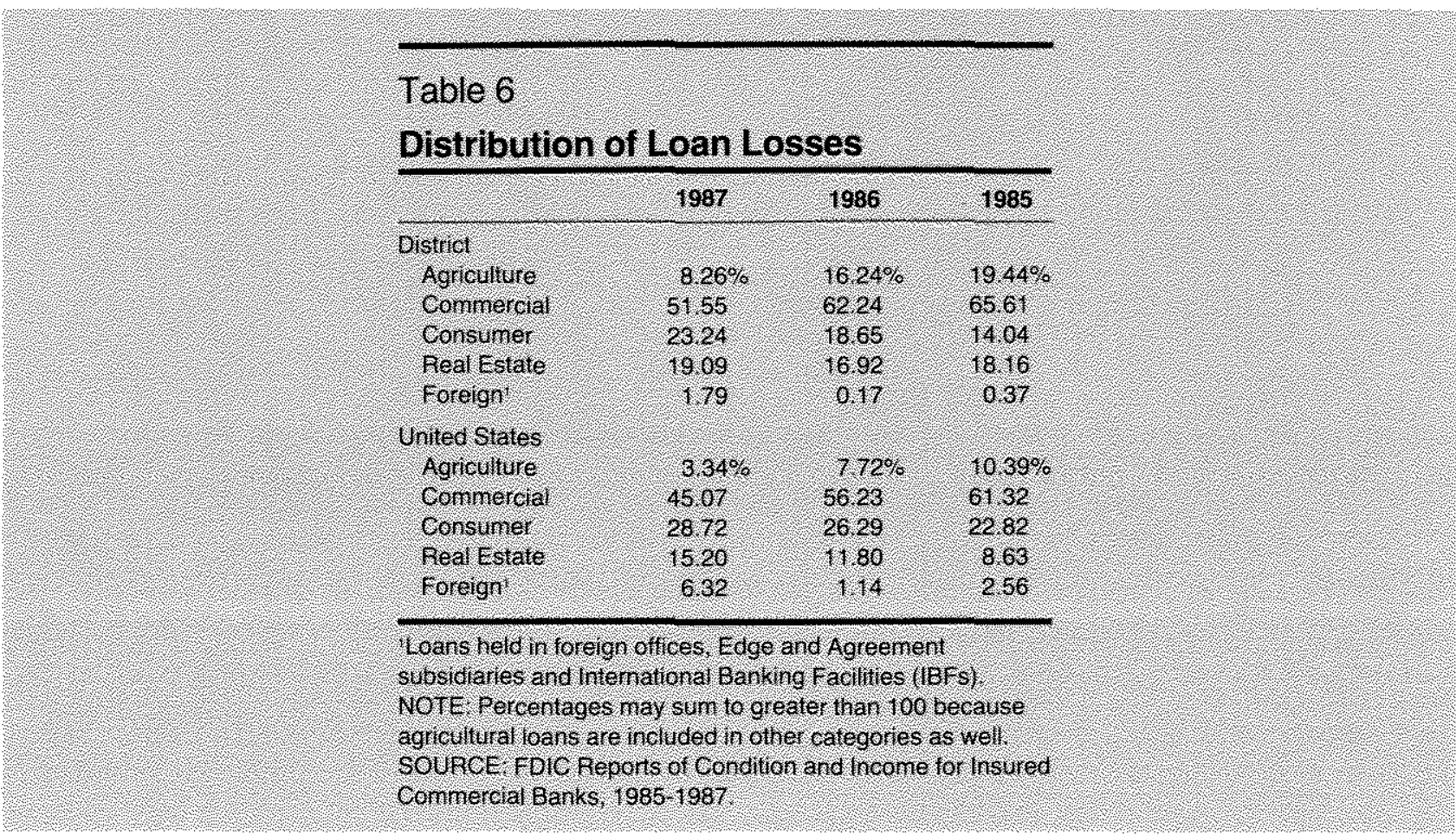

types. As one can see from the chart, the loss rate was highest for District agricultural loans, with commercial loans a close second. As a percent of total agricultural loans outstanding, 1.92 percent were charged off in $1987 ; 1.41$ percent of commercial loans were classified as a loss.

\section{Loan Loss Resene}

Mounting loan losses have decreased the average profitability of banks. The relationship between the loan loss provision, which is an income statement item, and the loan loss reserve, which is a balance sheet item, can be shown as follows:

$$
\begin{aligned}
& \text { Beginning Loan Loss Reserve } \\
+ & \text { Loan Loss Provisions } \\
+ & \text { Actual Charge Offs } \\
+ & \text { Recoveries } \\
= & \text { Ending Loan Loss Reserve, }
\end{aligned}
$$

Any addition to the loan loss provision directly reduces profits.

As table 7 shows, banks in the Eighth District and the nation continued to add to their loan loss reserve and loan loss provision accounts during 
Chart 2

Loan Losses

as a Percentage of Total Loans by Category

Eighth District

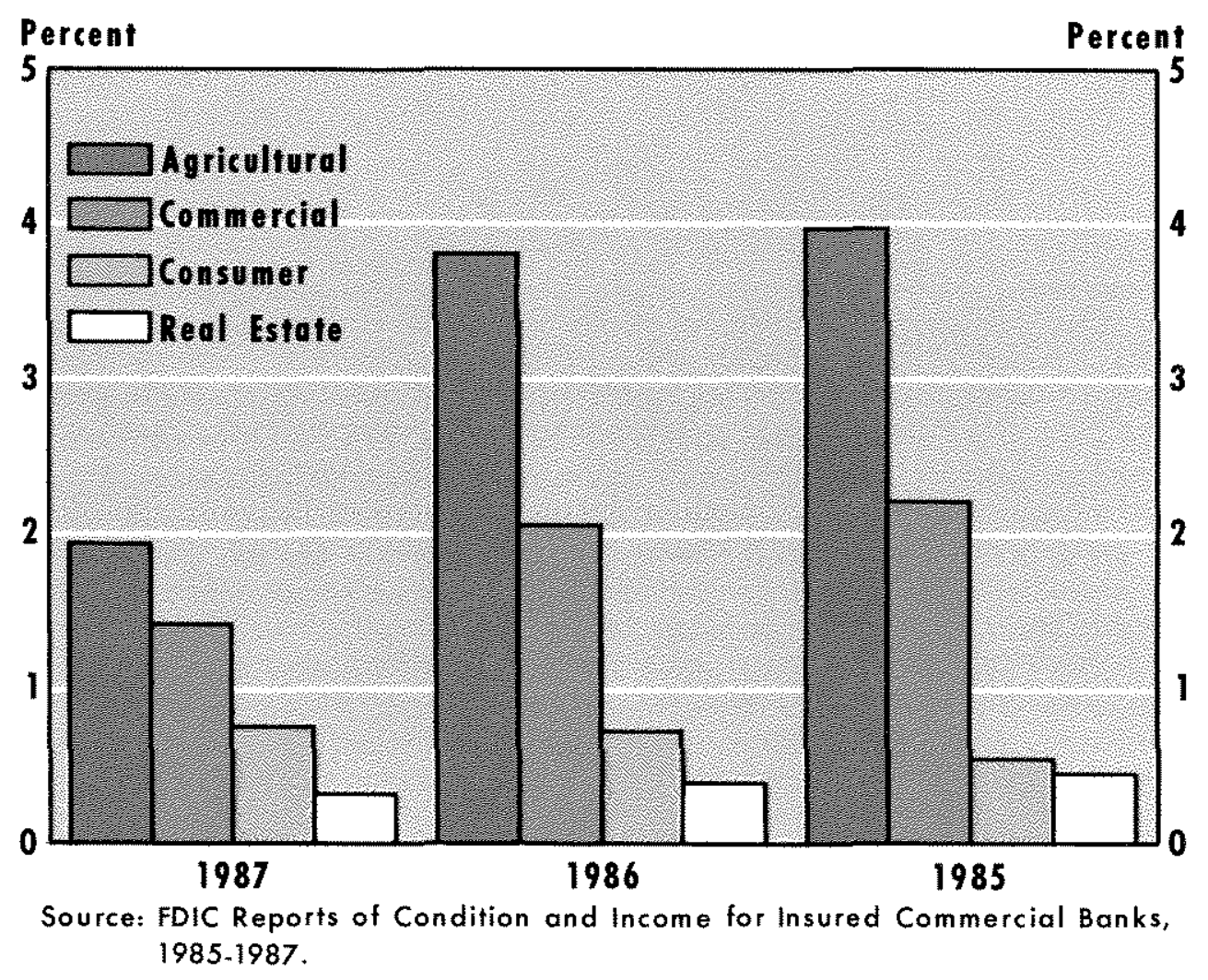

1987. As a pereent of lotal loans, Eighth District banks' loan loss reserve increased from 1.41 percent in 1986 to 1.67 percent in 1987; nationaly, this ratio rose from 1.63 percent to 2.70 percent. The largest District banks increased their reserves to 2.15 percent of total loans, up from 1.40 percent at year-end 1986. Nationally, banks with assets greater than $\$ 10$ billion increased their reserve levels substantially in 1987; as a percent of lotal loans, 4.25 percent were covered by reserves, compared with 1.83 percent in 1986 .

Loan loss provisions totaled $\$ 694.2$ million at District banks at year-end 1987 , up $\$ 40.3$ mallion from 1986 levels. Nationaly, banks added $\$ 14.8$ billion; and at year-end 1987 , the loan loss provision account stood at $\$ 36.3$ billion. This action was taken as a precautionary measure to absorb expected future loan losses. Many large banks added to their loan loss provision account in June 1987 fo allow for the deterioration of their foreign loan portfolio. A second round of provision increases occurred during the fourth quarter. By year-end 1987, most banks had set up reserves equal to approximately 50 percent of their Latin American exposure.

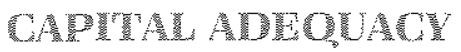

Bank regulators have a strong interest in ensuring that banks maintain adequate financial capital the difference between their assets and liabilities! The level of bank capital serves to maintain public confidence in the soundness of the individual bank and the banking system as a whole. Bank capital is intended to absorb losses, custion against risk, provide for asset expansion and pro- 


\begin{tabular}{|c|c|c|c|c|c|c|}
\hline $\begin{array}{l}\text { Table } 7 \\
\text { Loan L oss mese }\end{array}$ & duga & $\operatorname{loss}$ & ovisio & & & \\
\hline & \multicolumn{2}{|c|}{1987} & \multicolumn{2}{|c|}{1986} & \multicolumn{2}{|c|}{1985} \\
\hline & Distifict & uss. & Pistriat & Us. & Distrid & US. \\
\hline Loan Loss Reserves & & & & & & \\
\hline All banks ? ४ ४ ४ & $1.67 \%$ & $270 \%$ & $144 \%$ & $1.63 \%$ & $1.31 \%$ & $142 \%$ \\
\hline 0.625 nillion in assets & 160 & 186 & 160 & 180 & 1.59 & 1.54 \\
\hline $825-\$ 50$ millon & 150 & $17 \%$ & $1 \longdiv { 4 4 }$ & 1.61 & 1226 & 139 \\
\hline$\$ 50 . \$ 100$ rilliton & 1.44 & 1.53 & 1.43 & 1,54 & 1.22 & 1,36 \\
\hline S 800 . $\$ 300$ millon & 1,32 & 1.50 & 1.31 & 148 & 1.19 & $\sqrt[131]{131}$ \\
\hline \$ 8300 minion 10 bilion bition & $\frac{1.32}{2.15}$ & 1.58 & 1,48 & 1,87 & 1.96 & 1,37 \\
\hline 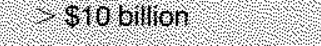 & $\sqrt{1} \cdot 4$ & 425 & NA & 183 & NA & 1,53 \\
\hline Loanloss Provisions & & & & & & \\
\hline Albanks & $0.60 \%$ & $123 \%$ & $0.50 \%$ & $077 \%$ & $0.59 \%$ & $0.67 \%$ \\
\hline . $\$ 25$ mulon n assets & 0.47 & 0.81 & 10.60 & 114 & 0.80 & 106 \\
\hline 856.550 millon & 0.43 & 0.69 & 067 & 696 & 0.76 & 087 \\
\hline 0850 o 100 nillon & 0.61 & 0.68 & 0,61 & 084 & 064 & 081 \\
\hline 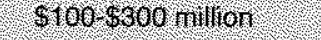 & 1045 & 0.53 & 0.63 & 074 & 063 & 062 \\
\hline 8300 niliton s 1 billon & 042 & 066 & 9.60 & 082 & 061 & 0.68 \\
\hline 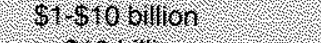 & 097 & 088 & 046 & 067 & 043 & 0.56 \\
\hline 4.51069107 & 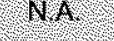 & 202 & NA & 0.80 & NA & 070 \\
\hline
\end{tabular}

tect uninsured depositors. Moreover, additional capital can reduce the exposure of the Federal Deposit Insurance Corporation (FDIC) to bank losses. When a bank lails and is liquidated, the FOlC's loss equals the bank's liabilities minus the market value of the failed bank's assets. Therefore, the greater proportion of assets funded by capital rather than by liabilities, the smaller the potential loss to the FDIC insurance fund, all other things equal. The regulatory agencies have set minimum standards of 5.5 percent primary capital to assets and 6.0 percent total capital to assets?

Improvement in bank capital ratios in recent years is apparent throughout the range of institu- tions. As indicated in table 8, total capital ratios are well above the minimum standards established by the bank regulatory agencies both for banks in the Eighth District and the banking industry as a whole. "The average total capital ratio the sum of the individual banks' total capital divided by the sum of the individual banks' total assets) was 8.86 percent for Fighth District banks in 1987, compared with 8.38 percent for all U.S. commercial banks. As of December 1987, approximately 1.4 percent of all District banks did not meet the minimum regulatory total capital standards, while slightly more than 4.4 percent of the commercial banks in the nation had deficient total capital ratios.
7 The components of primary capital as reported in the FDIC Consolidated Report of Condition and Income are: common stock, perpetual preferred stock, surplus, undivided profits, contingency and other capital reserve, qualifying mandatory convertible instruments, allowance for loan and lease losses and minority interests in consolidated subsidiaries, less intangible assets excluding purchased mortgage servicing rights. (For the purposes of this paper, only the goodwil portion of intangible assets was deducted.) Secondary capital is limited to 50 percent of primary capital and includes subordinated notes and debentures, fimited-life preferred stock and that portion of mandatory convertible securities not included in primary capital. Each bank's secondary capital is added to its primary capital to obtain the total capital level for regulatory purposes.

\begin{abstract}
'The regulatory agencies do not assume that a bank's capital is adequate simply because it meets the minimum capital requirements. Banks whose operations involve higher degrees of risk are expected to hold additional capital. The Federal Reserve Board, Federal Deposit Insurance Corporation and Office of the Comptroller of the Currency have formally proposed risk based capital guidelines that would apply to all U.S. banks. The proposal would tie a bank's capital to its asset risk and require additional capital to support off-balance-sheet activities. This risk-based capital plan would be phased in by 1992 , at which time banks would be required to maintain an 8 percent capitatto-asset ratio, half of which must be in common equity and disclosed reserves.
\end{abstract}




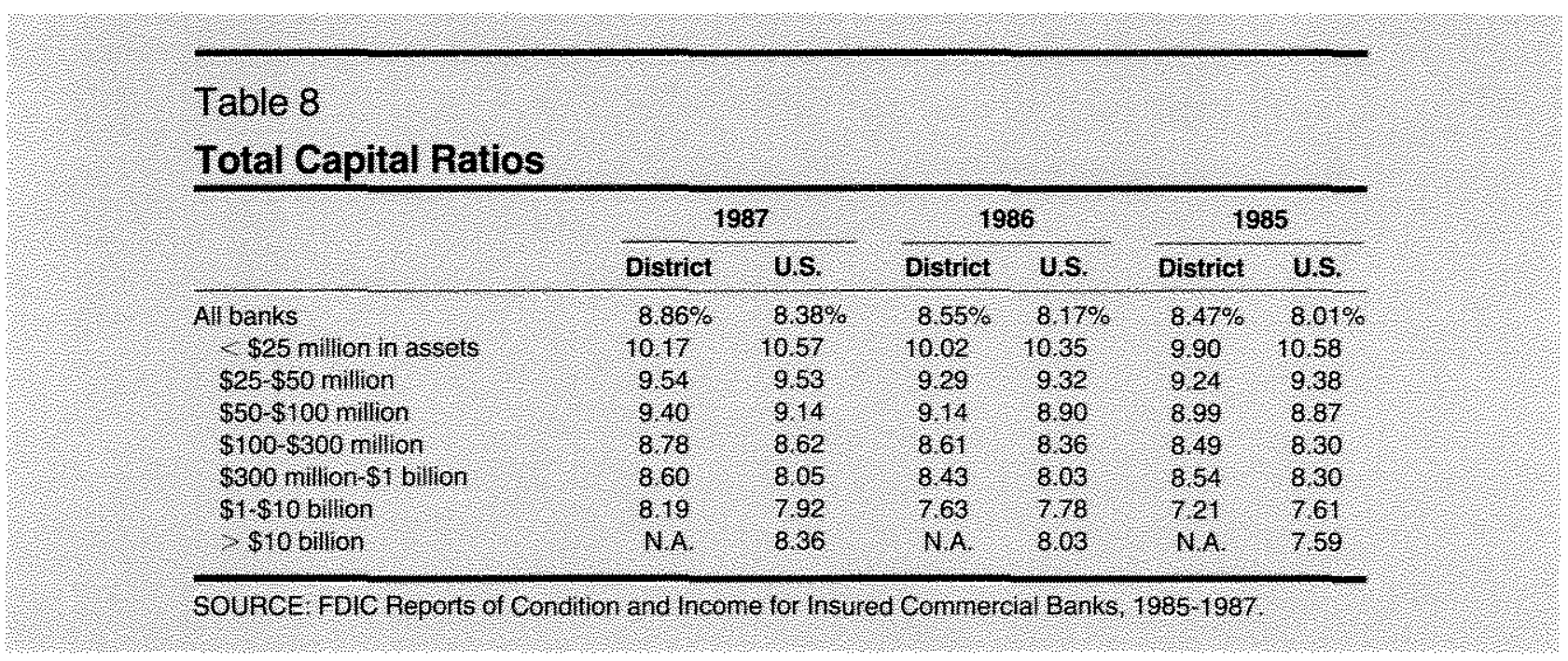

\section{SUMIVIVAV}

The financial performance of banks in the Eighth Federal Reserve District, like that of banks in the nation, was poor for the largest banks but improved for the smaller banks. Profits at the larger banks were adversely affected by above. normal loan loss provisions and problem loan levels that, while moderating, remained high by historical standards.

District net interest margins declined in 1987. As an offset to interest income, banks have been concentrating their efforts on fee income. Al though 1987 overhead levels stabilized, overhead costs have been trending upward for the past sevm eral years, culting into profits. Compounding the pressure on earnings from rising overhead costs are the loan loss provisions required to strengthen loan loss reserves. These provisions rose sharply in 1987 , as a result of a deterioration in the District's foreign loan portfolio. The overall level of District nonperforming loans decreased slightly in 1987; and loan losses at District banks, which had been rising in recent years, declined in 1987 . Finally, a majority of Eighth District banks improved their capital ratios in 1987 and are positioned well above the minimum standards set by bank regulators. 